\title{
Louise Zeuthen
}

\section{Uden på munkekutten en bikini}

\author{
Performative spor hos Kirsten Thorup \\ og samtidige kunstnere
}

På sidste side af Bonsai indtaler hovedpersonen Nina følgende gådefulde ord på en båndoptager. De er rettet til Charlotte, Ninas psykoanalytiker:

W Jeg vil med det samme understrege, at jeg er en kvinde inderst inde og endnu længere inde er jeg mand og helt inderst - der hvor hverken habitten eller det bløde kød når ind, og hvor der er lige så varmt som i Skærsilden og varmt nok til at kvinden og manden smelter sammen - er jeg kønsløs. Men dér kommer jeg kun i tankerne. (266)

Umiddelbart giver disse ord ikke mening i forhold til Bonsais øvrige historie om Nina og Stefans fatale kærlighedshistorie. Hvad er det for en størrelse, dette kønsløse jeg, der unddrager sig både habitten og det bløde kød, og som kun kan nås af tankens vej? Og hvilken forløsning - hvis det da er en forløsning - repræsenterer denne idé for Bonsais i øvrigt katastrofiske narrative forløb? ${ }^{\mathrm{I}}$

Det er interessant, at en anden af Thorups store romaner, Himmel og helvede, også afsluttes abrupt af en lige så ubegribelig replik, der kredser om køn og krop - ligeledes som en art forløsning på et langt og vidtforgrenet narrativt forløb. Replikken er denne gang lagt i munden på jeg-fortælleren, Jonnas bror, der beskriver sin søster for sin nye kone Maria. Men Jonna udfylder sin rolle som jeg-fortæller og søster til én af personerne på en højest usædvanlig måde. Det er først her, på de sidste to sider af den over sekshundrede sider lange roman, at konturerne af hende overhovedet træder frem. Alligevel forbliver hun - som Nina i Bonsai - svær at fastholde som et individ med køn og krop. Jonnas bror siger:

[Hun har] den samme måde at være der og så alligevel ikke være der. Hvis du forstår hvad jeg mener. Sådan en irriterende larmende måde at være stille på. Hun går også i noget mærkeligt tøj [...] Men hun er klog. Det siger de ihvertfald. Så klog at hun kan undvære hovedet. [...] Men helt almindelig er hun ikke. Hun snakker og tænker akkurat som en mand. Kan du ikke se det for dig? Og så kan hun være så pissepåståelig. 
Man får ikke et ben til jorden. Man føler sgu ikke at det er en kvinde man er sammen med. (613-14)

Interessen for kønskategorier som bærere af betydning i forhold til identiteten - eller måske snarere kategoriernes mangel på samme - er et centralt tema i Kirsten Thorups forfatterskab. Går man tilbage til første del af romanserien om Jonna, Lille Jonna, slås temaet om køn og identitet da også an fra begyndelsen i kapitlet med den - i forhold til kønsdikotomier - sigende titel: "En lus mellem to negle". Kapitlet omhandler den lille Jonnas spirende interesse for det modsatte køn, som kommer til udtryk som hemmelige iagttagelser af og kærlighed til den ældste bror. I den tiårige Jonnas øjne er broderen symbolet på “'den anden’, den elskede, en kammerat som står ved ens side i den store verden." (Lille Jonna: 11) Men hun afslører aldrig sin længsel overfor ham. Tværtimod gør Jonna alt for at være usynlig og lydløs i nærheden af sin storebror, som hun gerne vil smelte sammen med og blive en del af.

I både Lille Jonna, Himmel og helvede og Bonsai er udforskningen af hvorvidt (og hvordan) kønnet skaber identitet således forbundet med fravær og tavshed. Den lille Jonna omgærder sin interesse for storebroderen i tavshed i et fors $\varnothing g$ på at gøre sin tilstedeværelse og interesse ubemærket. I Himmel og helvede (1982) er Jonnas nærvær som jeg-fortæller ligeledes karakteriseret ved et bemærkelsesværdigt fravær. Og endelig er man stærkt i tvivl om, hvorvidt man kommer nærmere Ninas "virkelige" identitet til sidst i Bonsai, eller om hun snarere forsvinder helt i hudlag, habitter og andre klædningsstykker. Væsentligt er det nemlig, at også fortællerstemmen er tavs med hensyn til, hvordan de mest centrale aspekter af fortællingerne skal fortolkes. Tavshed og fravær gennemsyrer værkerne både på det tematiske niveau og på det æstetiske. Disse tavsheds- og fraværsstrategier, der kendetegner Thorups måde at undersøge den realistiske prosas mulighedsrum i forhold til fremstilling af $k ø n$ og identitet, er emnet for denne artikel. Hensigten er således ikke at komme med egentlige værkanalyser, men i stedet at pege på nogle af de performative tendenser i Thorups værk, der skaber forbindelse mellem hendes forfatterskab og andre kunstnere fra samtiden.

\section{Nærværs- og fraværsstrategier}

Thorup er ikke den eneste af sin generation, der i løbet af halvfjerdserne bliver optaget af at udforske prosaens muligheder og begrænsninger, når køn og identitet skal beskrives. Suzanne Brøgger og Dan Turèll indleder også i denne periode litterære projekter, der har til formål at afsøge grænseegnene mellem fiktion og virkelighed, og at undersøge, hvorledes identitet og køn overhovedet kan fremstilles. Fælles for disse tre forfatteres bestræbelser er en insisteren på virkeligheden i hele dens mangfoldighed - både det private, intime, hverdagen og det politiske hører med, ligesom der heller ikke skelnes mellem det poppede, det folkelige, fin- eller massekultur.

Til forskel fra hvad man indtil nu har været tilbøjelig til at mene om halvfjerdsernes tilsyneladende naive realisme, bekendelsestrang og sociale indignation, så er interessen for virkeligheden hos nogle af forfatterne fra denne periode ikke udelukkende af tematisk art, men i højeste grad også æstetisk. Udgangspunktet har 
måske nok været et ønske om at kunne formidle virkeligheden i ufiltreret form, men i dette projekt bliver det helt centrale spørgsmål hurtigt, hvorvidt den umiddelbart nærværende og håndgribelige størrelse "virkelighed" overhovedet kan befærde litteraturen. Det kunstneriske projekt er fra da af ikke at repræsentere virkeligheden, men at sætte forskellige lag af virkeligheden i spil gennem kunsten. Herved forskydes perspektivet fra en naiv repræsentation af virkeligheden til en postmoderne repræsentationskritisk tilgang. Spørgsmålet er ikke længere, hvad virkeligheden er, for den er i princippet alt; både den rå uformidlede virkelighed, de subjektive genfortællinger og konstruktioner af virkeligheden, de kunstneriske repræsentationer og massekulturens billeder. I stedet retter interessen sig mod hvilke relationer, der konstruerer virkeligheden. Med andre ord spørges der: Hvor er virkeligheden?

Uanset, at hver forfatter har sin særegne måde at sætte virkeligheden i spil på, er det alligevel muligt at udpege to centrale akser i dette felt, som netop er defineret omkring parametrene nærvær og fravær. Brøgger og Turèll benytter sig af det, som jeg vil kalde en nærværsstrategi, når de lader deres egen specifikke krop optræde som mere end nærværende størrelser i deres værker. Næsten som readymades placerer de sig selv midt i værkerne; det er imidlertid ikke et pissoir af porcelæn, men derimod konstruktionerne "Dan Turèll" og "Suzanne Brøgger", der sættes ind i en kunstnerisk ramme for at generere spørgsmål om kunst, repræsentation og virkelighed. Brøgger og Turèll kan ses som forløbere for forfattere som Claus Beck-Nielsen, Pablo Henrik Llambías, Lone Hørslev og Lars Frost. Også i deres værker støder man ind i forfatterne i forskellige udgaver, med pjerrotdragt, med krykker, som hjemløs, javist, men alligevel beærer disse personager tekstsiderne, uden at der dog er tale om entydige eller traditionelle repræsentationer af forfatteren. Tværtimod bryder den specifikke krop ind i teksten som en strategi, hvorved grænsefladerne mellem virkelighed og fiktion, mellem præsentation og repræsentation kan undersøges og udfordres. Mens Claus Beck-Nielsens kunstneriske identitetseksperimenter i grænselandet mellem fiktion og virkelighed er ret vidtgående i deres realisering, så kan man sige, at Llambías, Hørslev og Frosts måde at iscenesætte forfatteren på er mere afdæmpet. Ikke desto mindre drager også de deres egen person ind i værket - ikke i et naivt selvbiografisk ærinde, men som udtryk for en avanceret, postmoderne repræsentationskritik. ${ }^{2}$

Heroverfor benytter Thorup sig af den modsatte strategi - fraværets - når hun lader sine figurer forsvinde, blive tavse, blive skabelonagtige og konstruerede. En tendens, som videreudvikles og radikaliseres på forskellig vis hos Helle Helle, Solvej Balle, Kirsten Hammann og Pia Juul. Her er det netop alt det, der unddrager sig sproget, som sættes i fokus; det er "resterne", det handler om, for nu at bruge Helle Helles eget udtryk. ${ }^{3}$ Herved underliggør fremstillingerne hverdagen og virkeligheden. Man skulle måske tro, at det fører til, at man får øje på virkeligheden på en anden måde, end man plejer. Men det er ikke tilfældet. Man får ikke øje på virkeligheden, men på det faktum, at man aldrig kan nærme sig virkeligheden udenom disse fremstillingsformer, udenom klichéerne, diskurserne, sproget, uanset hvor utilstrækkelige de er. Underliggørelsen præger både personerne i værkerne og fortælleren. Selvom personerne til tider står knivskarpt frem, så bliver de ofte på afgørende tidspunkter mærkeligt konturløse i deres fremtoning. Ligeledes kan 
fortælleren det ene øjeblik beredvilligt øse af sin viden, det næste øjeblik er fortællerstemmen forsvundet, og læseren er overladt til sig selv. Endelig kommer dialogen også til at hænge mellem personerne i al dens utilstrækkelighed, hvilket endnu engang peger på kommunikationens utilstrækkelighed. ${ }^{4}$ Værker, der benytter sig af fraværets strategi, peger hele tiden på netop det sted, hvor diskurserne støder sammen med eller standser ved virkeligheden. Diskurserne og virkeligheden kan aldrig mødes. Det er i disse dissonanser mellem diskurserne og det narrative forløb, at værkets performative åbninger findes.

\section{Polkaprikker og makaroni}

Inden vi vender tilbage til en mere præcis beskrivelse af Thorups måde at betone fraværet og tavsheden på i sin fremstilling af køn og identitet, skal to performanceværker af henholdsvis Yayoi Kusama og Ana Mendieta anskueliggøre nærværets og fraværets kunstneriske metode. Omvejen er relevant, for det er helt tydeligt, at de litterære nærværs- og fraværsstrategier, som de danske prosaforfattere benytter til at sondere gråzonen mellem fiktion og virkelighed, er overensstemmende med den kunstneriske praksis, som bodyart-kunstnere fra tresserne og halvfjerdserne benytter sig af. Også her er det accentueringen af henholdsvis nærvær og fravær, der danner grundlag for repræsentationskritikken.

Collagen: Sex Obsession Food Obsession Macaroni Infinity Nets \& Kusama (1962), skabt af Yayoi Kusama godt ti år før Thorup skrev Lille Jonna, demonstrerer helt tydeligt en nærværsstrategi. Det er et påtrængende værk med et overskud af betydninger og diskurser. Kusamas collage fremstiller en næsten afklædt kvindekrop - kun et par højhælede sko og nogle påmalede polkaprikker kommer imellem kameralinsen og den nøgne hud. Polkaprikkerne, de hvide stof-dupper og makaronien repræsenterer de forskellige "besættelser", der præger Kusamas værk, hvilket den lange billedtitel henviser til; den seksuelle besættelse, besættelsen af mad og den æstetiske besættelse af polkaprikker. Hermed fremhæver Kusama flere af de diskurser, der i vores massekonsumerende varesamfund normalt fungerer i det skjulte. Kvinden er ofte - både i kunst og massekulturen - blevet fremstillet som en vare, der enten kan fortæres i overført betydning - eller blot nydes som æstetisk føde. Nøgenmodellen med det forførende blik og polkaprikkerne eksponerer de diskurser, der fremsætter kvinden som et objekt. Kunstobjektet er til for publikum og har ingen betydning ud over den, publikum giver hende. Her er det publikum, der bemægtiger sig fortolk-

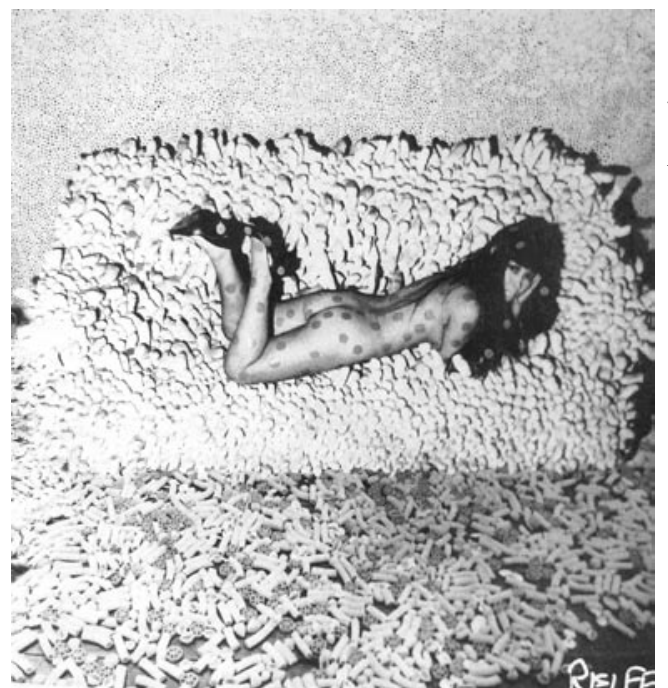

Yayoi Kusama: Sex Obsession Food Obsession Macaroni Infinity Nets \& Kusama, 1962. 
kan komme udenom sproget, diskurserne og i dette tilfælde billedsproget, når man vil repræsentere virkeligheden, så er dette værk trods alt tæt på at være en - i hvert fald billedlig talt - "ren" fremstilling af subjektet.

Mens Kusama betoner nærværet, så virker Mendietas billedserie ved fraværet fraværet af analyserbar teknik, fraværet af genkendelige diskurser og fortolkningsnøgler. Fraværet af den krop, der formede silhuetten, efterlader ligeledes et savn i billedet, et ekko af længsel og død. Til sidst er selve aftrykket efter Mendieta og den røde farve også forsvundet med bølgerne, kun sandet er tilbage. Fraværsæstetikken giver ikke fortolkeren meget at arbejde med. Interessant er det imidlertid, at denne fraværsæstetik har samme effekt som Kusamas påtrængende betydnings-overkill. Det eksponerer både beskuerens rolle i fortolkningssituationen og blotlægger de diskurser, som fortolkningen baseres på - som konstruktioner i stedet for usynlige sandheder.

Eksempelvis vil de fleste beskrive værket som afbildningen af en kvinde, uanset om man kender til Mendietas rolle i værkets tilblivelsesproces, og uanset figuren i sandet ikke bærer nogle definitive kønsmarkeringer. Det skyldes især de bløde former, den røde farve, der sammen med figurens kurver ikke alene giver associationer til kvindens krop, men også til livmoder og æggeledere; og endelig det faktum, at værket er skabt som en del af naturen. Naturen og jorden er traditionelt set kvindelige symboler. Men i stedet for at bekræfte de kulturelt skabte og usynligt virkende fortolkningsgrundlag, så fremhæver fraværet af den egentlige krop, at disse diskurser og fortolkningsnøgler stammer fra beskueren. De udgør altså hverken nogen essentiel sandhed om kvinden eller om værket, men er subjektive og kulturelt skabte diskurser.

Som det ofte er tilfældet i forhold til kunst, der driller ved ubestemmelige henvisninger til kunstneren selv, så griber mange fortolkere af Mendietas værk til biografiske læsninger - i mangel af bedre. Af den grund er værket blevet tolket som en længselsgestus, som en skildring af Mendietas længsel efter sit hjemland, Cuba. I 1961 blev hun sammen med sin søster sendt i eksil fra Cuba til USA. Hun var på det tidspunkt kun tolv år, og hun tilbragte de næste fem år hos tre forskellige plejefamilier og en kostskole. Hun genså først sit hjemland som voksen, og i flere interviews beskriver hun sit liv i eksil som afgørende for sit kunstneriske projekt. Det virker derfor naturligt at læse værket som et billede på Mendietas hjemløshed, som et (umuligt) forsøg på at finde sin plads på/i jorden. Jeg mener imidlertid, at en udelukkende tematisk fortolkning negligerer værkets æstetiske betydning og deraf også dets betydning for kunsthistorien.

Den biografiske læsning findes bestemt som én mulig fortolkning - men ud af mange forskellige. Mendietas performance kan ikke analyseres som et lukket, autonomt værk, hvis betydning kan aflæses indenfor rammerne af det repræsenterede. Det giver ingen endegyldige svar på spørgsmål som: Hvem er Ana Mendieta? Eller: Hvad er kvinden? I stedet spørger værket, både helt konkret, men også i overført betydning: Hvor er Ana Mendieta? Det vil sige: Hvilke relationer og hvilke diskurser skaber forestillingerne om køn og identitet? ${ }^{6}$ Værket eksponerer de diskurser, som sættes i spil mellem værk og beskuer - det biografiske, traditionel symbolik og personificeringer. Akkurat som Kusamas værk præsenterer Mendietas performance 
snarere vilkårene for repræsentation, end en bestemt repræsentation af kvinden. Lige der, hvor kroppen støder på sand og vand, skabes forestillingen om en kvinde, med et dertilhørende utal af kulturelt bestemte forestillinger og narrativer. Det er ikke til at sige, om figuren skabes af materialet, sandet, eller tomrummet efter Mendietas krop. I al sin enkelhed fremhæver værket blot, at det er i sammenstødet mellem subjekt og virkelighed, at forestillingerne om identitet og køn produceres og subjektivitetseffekten skabes. Det er dette sammenstød, Mendietas værk iscenesætter på performativ vis, således at også beskueren trækkes med ind i betydningsdannelsen.

\section{Selviscenesættelse eller tavshed}

Som det burde fremgå af ovenstående, så er nærværs- og fraværsæstetikken to sider af samme performative sag. Derfor vil de to strategier ofte glide over i hinanden i det enkelte værk, virke side om side eller måske blot bære den modsatte strategi i sig som dens komplementære størrelse. Alligevel er det tydeligt, at Dan Turèll og Suzanne Brøgger - med deres mere end nærværende selviscenesættelser både i det enkelte værk og i det kulturelle rum - har mere til fælles med Kusama end med Mendieta. Akkurat som Kusamas collage eksponerer de forskellige måder, hvorpå "kvinden" - både i en specifik udgave med en særlig historie og fremtrædelsesform og i en mere generel forstand - bliver repræsenteret. Turèlls og Brøggers værker kan ses som en undersøgelse af og spejling af, hvordan henholdsvis manden og kvinden repræsenteres i dansk kulturliv anno halvfjerdserne og frem. Deres værker kan ses både tematisk og æstetisk som præcise målinger af de rystelser, som massekulturens fremkomst afstedkommer, hvor identiteten pludselig kommer til forhandling i et utal af fora, og hvor mange forskellige medier ønsker at gøre deres "genfortælling" gældende.

Ligeså frugtbar som sammenligningen mellem de danske selviscenesættende forfattere og Kusama er, synes sammenstillingen mellem Mendietas kunstneriske strategi og Thorups også at være, selvom Thorups mastodontværker til tider også synes overlæssede med betydninger og stemmer. Men det er især ved hjælp af tavshedens og fraværets æstetik, at Thorup formår at pege på det materiale og de diskurser, som den traditionelle realisme bygger på. Hvor Mendietas materiale i dette værk er sandet og bølgerne, er Thorups materiale den realistiske prosa. Alligevel er strategien den samme. Også hos Thorup synes subjektet med køn og med krop at undslippe materialet - i dette tilfælde i sidste ende det realistiske formsprog - som sand mellem hænderne på læseren. Fraværsæstetikken sætter fokus på alt det, som skaber subjektivitetseffekten, diskurserne, materialet, sproget, de betydningsbærende tegn. Paradokset er, at man ikke "er nogen", man har hverken identitet eller køn, hvis ikke man bliver repræsenteret af en diskurs, et medie eller en genre overfor en "anden". Men disse repræsentationssystemer modsvarer aldrig helt virkeligheden, der er altid en rest, som ikke kan rummes af de tilgængelige kommunikationsformer. Thorups værker skildrer dette paradoks. 


\section{Kirsten Thorups fraværsæstetik}

Lad os igen vende os mod de i indledningen nævnte passager fra henholdsvis Lille Jonna, Himmel og helvede og Bonsai, idet de meget præcist skildrer, hvordan Thorups fraværsæstetik bliver til og virker i hendes romaner. Alle tre passager beskriver omstændigheder, hvor størrelser som køn, identitet, seksualitet og kærlighed unddrager sig de vanlige diskurser. Personerne kæmper for at forstå sig selv og hinanden, men er altid i sidste ende overladt til utilstrækkelige diskurser i forsøget på at kommunikere med den "anden".

At identitet og køn er størrelser, der skabes i forhold til den "anden", hvorved tavsheden bliver problematisk, er allerede et tema i Lille Jonna. Men her har det endnu ikke fået så store æstetiske konsekvenser for forfatterskabet. Det er nok kun med bagklogskabens bedreviden, at man får øje på, at fortælleren Jonna allerede her springer ud af sin barnekrop nu og da. Eksempelvis bliver hun til en "urealistisk" litterær konstruktion, når hun med en detaljerigdom beretter om episoder, som hun ikke burde kende til, da hun ifølge det narrative forløb ikke har været til stede.

Først i Himmel og helvede forplanter Thorups performative strategi sig både tematisk og æstetisk, især hvad angår beskrivelsen af Jonni og Marias mislykkede ægteskab, hvor Jonnis dagbog kommer til at udgøre den tredje, fatale pol. Omkring dagbogen fortætter romanens udforskning af køn og identitet sig både på det narrative og det formelle niveau, idet den bliver det helt centrale omdrejningspunkt for Thorups udforskning af forholdet mellem repræsentation og virkelighed. Dagbogen præsenteres i første omgang som et vindue til verden, sådan som Jonni - i hvert fald til dels - oplever den. Men idet dagbogens afsnit relativeres af både Jonnis og Marias øvrige oplevelser og den alvidende fortællers kommentarerer, bliver dette "vindue til verden" i anden omgang eksponeret som blot én fortælling blandt mange. Idet dagbogen ikke kommer til at fungere som den sidste brik i et uforståeligt narrativt puslespil, forskydes dagbogsteksten fra at være en hemmelig tekst, der kan tilbyde læseren "sandheden" om Jonni, til blot at være én fortolkning af begivenhedernes betydning blandt flere mulige, baseret på én (utilstrækkelig) diskurs blandt flere mulige.

Det er tydeligt, at dagbogen ikke bringer narrativ forløsning og identitet med sig, men død. Da Maria ved et tilfælde finder Jonnis dagbog, vægrer hun sig i første omgang kraftigt ved at åbne heftet. Hun fornemmer, at det, hun vil få at læse, vil "være sin egen dødsdom", (251). Marias frygt viser sig - i hvert fald i symbolsk forstand - at være begrundet. For da hun på trods af sin indre modstand læser videre, er det kun for at erfare, at hun ikke på noget tidspunkt figurerer på dagbogens sider. Maria erfarer ved læsningen af dagbogen, at Jonnis begær er rettet mod en anden mand. Hendes fravær i den elskedes bevidsthed beskrives ganske som en art død:

G Og mens hun læste vidste hun, at hun ville komme til at fortryde det. Og alligevel blev hun ved. Men der stod ikke noget om hende, ikke et ord. Hendes mavesæk snørede sig sammen. Det var som om hun ikke eksisterede. (252)

Men det er ikke kun for Maria, at den uventede afsløring føles fatal. Da Jonni senere i romanens forløb opdager, at Maria kender hans hemmelighed, beskrives det med samme metaforer: 
6 Han havde uden at vide det ligget opsprættet på operationsbordet med sine indre organer blottet til offentlig beskuelse. Det var for ham værre end døden. Det var en ophævelse af hans eksistens. (325-26)

Det er imidlertid væsentligt at lægge mærke til, at for Jonni er følelsen af at blive sprættet op ikke alene knyttet til den afsløring, som Maria ved sin læsning er katalysator for. Allerede forinden beskriver han oplevelsen af at være splittet:

6 4 Man kan sige at jeg er to personer. Den indre og den ydre. Den indre forekommer kun i dagbogen. Den ydre er den der skal fungere i mit arbejde og i forhold til andre mennesker. Der er ingen af de to personer der er den rigtige. De er mig begge to. Men jeg føler en større og større afstand mellem de to og bliver let stresset. Rent fysisk ytrer det sig sådan at jeg har fornemmelsen af at mit hoved er ved at sprænges. (252)

For Jonni afspejler dagbogen altså ikke hele den "skjulte sandhed" om ham, den beskriver én fortælling om ham. Romanen beskriver mange andre fortællinger om Jonni, der er lige sande. Når man på andre måder end gennem dagbogen får adgang til hans tanker, ser vi, at han også elsker Maria, men disse tanker finder altså ikke vej til dagbogen. Romanen præsenterer hverken i dagbogen eller andre steder én hel og harmonisk fortælling om Jonni, men lægger forskellige dele frem. Delene udgør ligeværdige repræsentationer af hans jeg; problemet er blot, at de forskellige dele ikke kan formidles med samme sprog og således heller ikke kan skrives sammen i én sammenhængende historie.

For Maria viser det sig, at det "at komme i dagbogen" heller ikke har den forløsende effekt, som hun og læseren har forventet. Da hun endelig - efter et stort opgør med Jonni - føler sig sikker på, at hun vil blive indskrevet i dagbogen, beskrives også det som en form for død: "Hun var helt rolig som den der har nået bunden og ikke kan synke længere ned. Hun gik i seng og faldt i en dødlignende søvn." (307) Betegnende er det også, at da Maria endelig erfarer, at hun er blevet skrevet ind i det brune hefte, får læseren intet at vide om hendes tanker eller følelser. Der står blot, hvad hun ikke tænkte på! Jonni beskriver da også Maria med de sigende ord: "Jeg vil næsten sige, at hun er blevet en anden." (322)

Man kunne mene, at Maria får muligheden for at "leve videre" som figur, efter at hun er kommet i dagbogen. Det gør det muligt for hende at løsrive sig fra Jonni, hun begynder at spille violin igen og bliver gift med John. Men en sådan fortolkning må i sidste ende baseres på læserens længsel efter at se figurerne leve og udvikle sig, ikke på romanens egne udsagn eller æstetiske effekt. Kærlighedsforholdet mellem John og Maria synes ikke at have samme dramatiske nødvendighed som forholdet mellem Jonni og Maria har. Og når det narrative forløb ikke længere holder læseren fanget, bliver romanens lidt tvungne og konstruerede brug af det realistiske formsprog desto mere tydeligt.

Romanen bliver underligt køns- og karakterløs efter at dagbogen har gjort en ende på kærlighedsforholdet mellem Maria og Jonni. Det er der flere eksempler på. Romanens ejendommelige valg af navne og dens gentagne postulater om de mest usandsynlige tilfældigheder er i den grad uforenelig med den traditionelle realis- 
mes påbud om, hvordan en sandsynlig virkelighed kan tage sig ud. At Marias nye kæreste hedder John, hvilket blot er en forkortet og afledt form af Jonni, synes ligeså mærkværdigt som det forhold, at romanen netop tryller John frem i det øjeblik, Jonni oplever: “...at han fik en anden bevidsthed i en anden tid og en anden krop." (490). At Jonni og John næsten deler mor, idet Ingrid kan beskrives som plejemor for John er ligeledes påfaldende. Men fordi man som læser er så forhippet på at fortolke forløbet som et stykke virkelighed, forsøger man at se bort fra mærkværdighederne ved at holde fast i fiktionens virkelighed som argument. Man siger til sig selv, jamen det er måske et besynderligt sammentræf, men John fandtes jo i forvejen, han er jo Jonnas bror!

Denne form for trøst kan kun fastholdes indenfor en traditionel realistisk ramme. Idet romanen afsluttes med en klar påmindelse om, at Jonna er en fortælleteknisk konstruktion, forsvinder den sidste rest af "virkelighedsillusion". Eksponeringen af, at fortællerstemmen naturligvis er en æstetisk foranstaltning uden kød og blod, vendes således bagud og påvirker hele romanen med tilbagevirkende kraft. Hvis man ser på dagbogen som led i en overordnet performativ fraværsæstetik, så bliver det tydeligt, at dagbogen bliver det sted, hvor hele den mere eller mindre realistiske verden, der er præsenteret i Himmel og helvede, bliver suget ind og forsvinder. Som læser er man efter endt læsning klar over, at der er noget, der ikke helt er gået op. Romanen får ikke bundet de løse ender af uforløst begær, uforløst kærlighed og uforløst søgen efter identitet og mening med tilværelsen, der ved dens afslutning giver ekko af mangel, fravær og i sidste ende død. Og det er i denne tomhedsfølelse at læseren bliver suget ind i romanen og selv begynder at binde sløjferne. Men som det var tilfældet ved Mendietas performance, så står disse fors $\emptyset g$ på at skabe betydning for læserens egen regning.

\section{Hul på genren}

Så vidt jeg kan se, er dagbogens utilstrækkelighed i forhold til at give Maria og Jonni en fælles identitet et billede på diskursernes utilstrækkelighed i det hele taget i forhold til køn og identitet. I et interview i Den Blå Port 59/60, formulerer Thorup det selv meget præcist:

6 4 Meget af det, jeg har skrevet, bryder lidt med genrerne. Jeg føler tit med en genre, at den er meget god, men jeg er altid nødt til at lave lidt om. Der er ikke nogen genre, jeg kan sige passer mig. Der er altid lige lidt, jeg skal slå hul på, der er altid lige lidt, jeg ikke kan indordne mig under. Ellers passer det ikke med det, jeg vil sige. (17)

I Himmel og helvede er det realismens diskurser, der bliver eksponeret, og de traditionelle forestillinger om $\mathrm{k} ø$, seksualitet og identitet, der forkastes som utilstrækkelige, hvilket efterlader et hul af fravær - akkurat som hos Mendieta. Ikke mærkeligt, at Thorup i Bonsai ser sig nødsaget til at vende tilbage til denne for hendes forfatterskab så påtrængende kortslutning mellem køn, seksualitet og identitet.

Bonsai er rendyrket performativ i sin æstetik. Gennem et kalejdoskop af stemmer spejles hovedpersonen Nina netop i relation til andre eller af andre. Hendes identi- 
tet bliver til i forhold til enten forældrenes, partnerens eller datterens forventninger. Det er kun i Ninas tale til psykoanalytikeren Charlotte, som er placeret som en art ramme om resten af romanen, at Thorup forsøger at mane Nina frem udenom de "andres" diskurser og billeder af hende. Dette fors $\emptyset$ g, som altså er placeret som henholdsvis begyndelse og afslutning på romanen, er baseret på mange paradokser. For at kunne formidle fortællingen om Nina og hendes kærlighed til Stefan udenom de ubrugelige diskurser, må Ninas fortællerstemme adskilles fra Ninas krop og antage andre identiteter og køn, blandt andet Kris' og Monas. Også deres kærlighedshistorie handler om kærlighed, svigt, død, selvmord, aktiv dødshjælp, om længslen efter både at blive sig selv og den anden og om kommunikationens utilstrækkelighed.

Den mærkelige historie om Kris og Mona spejler Nina og Stefans. Med denne historie tillader Nina sig selv - og i sidste ende naturligvis også Thorup - at give køb på den realistiske prosas snærende krav om årsagssammenhæng, om sandsynlighed, om logiske forbindelser mellem personerne, om traditionelle opfattelser af køn og identitet, i sit fors $\varnothing \mathrm{g}$ på at beskrive de sammenstød af diskurser, der kendetegner forholdet mellem Nina og Stefan.

Det er interessant, at Maria et sted i Himmel og helvede forsøger samme løsningsmodel. I en mærkelig drømmeagtig sekvens former Maria en fortælling, der virker forløsende, men som ikke kan forenes med det øvrige forløb:

6f Jonni, mumlede hun, hvis du kunne se mig nu ville du græde. For vi er skabt for hinanden. Men verden er ikke stor nok til os begge. [...] Jeg tror vi mødes igen, Jonni, engang efter 3. verdenskrig på en mørk landevej med hver sin tøjbylt under armen og hver sit stykke muggent brød under skjorten. [...] Du hører mig ikke råbe. Jeg eksisterer ikke for dig mere. Du er vendt tilbage til naturen. Jeg holder mig skjult i nærheden for at passe på at der ikke sker dig noget. Men jeg er uopmærksom. En dag ligger du i udkanten af skoven og er død. Jeg begraver dig hvor jeg fandt dig og overtager hytten og begynder at leve dit liv. (344-45)

Forudsætningen for sammensmeltningen med den "anden" synes at være forbundet med død og ikke-eksistens, og mødet kan kun finde sted i et ingenmandsland udenfor tid og sted. Afsnittene om Mona og Kris giver heller ikke mening, hvis de fortolkes som en realistisk del af den øvrige historie. Uanset at romanen lokker læseren til at forbinde Kris med den kriminalbetjent, der smittede Stefan, så mener jeg, at det vil reducere den æstetiske betydning, der ligger i disse afsnit. De er jo netop et opgør med de logiske, realistiske og sandsynlige årsagssammenhænge og motivationer for at drage personer ind på fortællingens arena. Læst i et performativt perspektiv fungerer afsnittene derimod - som vilde fors $\varnothing g$ på at slippe udenom forventningerne, udenom diskurserne og derved nærme sig virkeligheden fra en fraværsposition. Måske giver det mest mening, hvis det ses analogt med de afsluttende billeder fra Mendietas performance, hvor kun sandet er tilbage. Også Bonsais besynderlige afslutning skrives fra et nulpunkt, hvor det realistiske formsprogs grundlæggende regler er brudt, og kun temaerne om liv og død, køn og krop står tilbage.

Bogens afsluttende afsnit efterlader Nina køns- og identitetsløs "inderst inde", men med et væld af hudlag og klædningsstykker udenpå: 
6 I stedet for at fjerne huden og flå mig selv levende tager jeg et strutskørt uden på habitten. Og uden på strutskørtet en ulvepels. Uden på pelsen en munkekutte. Uden på munkekutten en bikini. Og det er foreløbig mit navn - også på grund af atomprøvesprængningerne i Stillehavet og de ulykkelige og mishandlede øer. (266)

De forskellige lag repræsenterer forskellige diskurser, psykologiske, sociale, kønsforskelle, kollektive og individuelle normer. Inden under disse lag findes mennesket, kønsløs og kropsløs med kun tankerne i behold. Billedet af denne fiktive person, Nina, er et meget klart performativt billede på realismens paradoks. Både forfatter og læser vil gerne - på fiktionens niveau - finde frem til sandheden om virkeligheden og om subjektet, men de er prisgivet diskurserne, der netop aldrig fører til nogen sandhed, men blot lægger sig som dræbende lag udenom figuren og virkeligheden. Spørgsmålet er også, hvilken form for subjektivitet, der findes udenom de mange lag af diskurser. Måske er der bare tavst og tomt som efter en atomprøvesprængning?

\section{Et performativt paradoks}

Set på det formelt-æstetiske niveau er det misforholdet mellem identitet og diskurs, der tager livet af Maria og Jonni, Nina og Stefan - i hvert fald når de anskues som konstruerede figurer på repræsentationens niveau. Hverken Jonni eller Nina, der via dagbogen og båndoptagelserne er de to romaners "forfattere", kan finde en fortælleform, der kan rumme hele deres identitet. De kan beskrive splittethedsfølelsen, men den kan ikke finde nogen narrativ forløsning. For Maria er problemet det samme, blot spejlvendt. Hvor Jonni kæmper med selv at skrive en meningsgivende historie om sig selv, søger Maria sin mening i hans historie om hende. Så længe hun ikke kan finde sig selv på dagbogssiderne, eksisterer hun ikke. Hun har ingen historie, før en anden indføjer hende i sin, ser hende og formidler hende.

At blive set af den "anden" forbindes med liv og død. Forholdet mellem eksistens og skrift - eller virkelighed og sprog - er da også en livsfarlig affære hos Thorup. Men det skal forstås i forhold til litteraturens evne til at beskrive virkeligheden, ikke i forhold til virkelige mennesker. Det livsfarlige består i sprogets utilstrækkelige og i sidste ende voldelige forhold til virkeligheden. På én og samme tid spørges der: Kan man overhovedet nærme sig virkelighed udenom sproget? Og: Kan sproget formidle virkeligheden uden at gøre vold på den? Det er imellem disse paradoksale og uforenelige spørgsmål, at Thorups forfatterskab former sig.

Paradokset er af performativ karakter. Det er Judith Butlers centrale pointe, at identitet og køn ikke er noget, man er, det er noget, man gør. Identiteten og kønnet skal hele tiden konstitueres overfor den "anden" gennem socialt acceptable handlinger eller genkendelige diskurser. Diskurserne er ikke til at komme udenom, men de skal ikke forveksles med sandhed. Identitet anskues ikke som sande, essentielle størrelser, men som dynamiske og foranderlige størrelser, der til stadighed er til forhandling. ${ }^{7}$

Idet den performative logik overføres til kunsten, kan værket ikke længere ses som en autonom størrelse, hvis betydning er indlejret indenfor rammerne af det lukkede værk. Værkets betydning skabes først, når værket gør noget i forhold til 
modtageren. Og det, som det performative værk gør, er at eksponere materialet og trække beskuer/læser ind i betydningsproduktionen. Da man jo ifølge den performative teori ikke kan komme udenom diskurserne, traditionerne og klichéerne, så vil et performativt værk ofte operere på to niveauer. På det ene niveau repræsenteres virkeligheden, kønnet eller identiteten på traditionel vis, på det andet sørger værket for at fremhæve det materiale, der bruges til at repræsentere, altså sproget og diskurserne, så de ikke fungerer i det skjulte. ${ }^{8}$

Måderne, hvorpå dette gøres, er mange, men når kunstnerens interesse er subjektet, køn og identitet, vil måden ofte kunne beskrives ud fra parametrene nærvær og fravær, som beskrevet ovenfor. I forhold til den realistiske prosa, som Thorup og eksempelvis Helle Helle udforsker, er det netop det traditionelle realistiske formsprog, der fremhæves. Værkerne præsenteres aldrig udelukkende som gennemsigtige vinduer til verden, men peger også på sig selv som vindue - som læseren hermed opfordres til at forholde sig til.

\section{Avantgarden og virkeligheden}

Ved at anlægge et performativt perspektiv på Thorups særegne måde at beskæftige sig med køn og identitet på, vil jeg gerne vise, at Thorups værk akkurat som Mendietas rækker ud over den traditionelle måde at opfatte køn og identitet på. Ja, det må snarere siges at dekonstruere denne opfattelse - og de litterære praksiser - der repræsenterer den.

Flere kritikere før mig har interesseret sig for Thorups køns- og identitetstemaer, ligesom også forfatterskabets udforskning af det tavse og fraværende er blevet diskuteret grundigt. Her bliver værkernes til tider mærkværdigt klodsede æstetik og de fortalte personers oplevelse af splittelse og fremmedgørelse imidlertid i sidste ende tolket som en konsekvens af Thorups egen kamp for at komme til skriften, og som et billede på hendes position som outsider i de københavnske kunstnerkredse. ${ }^{9}$ Men hermed fastholder man et traditionelt mimetisk synspunkt, som efter min mening reducerer Thorups værk og overser dets æstetiske betydning litteraturhistorisk set. Thorups værk mimer hverken en på forhånd eksisterende virkelighed eller virkelige mennesker. Thorups værk beder læseren om det, der er umuligt, nemlig at forholde sig til det, der ikke er repræsenteret, det, der er fraværende. Når Thorups æstetik bliver klodset, er det en måde at nedbryde de grænser, som traditionel realisme bygger på. Når Thorups værker skurrer i ørene eller skær i øjnene på den indre nethinde, har det netop til formål at pege på og eksponere de betingelser for repræsentation, som ellers er usynlige. I det øjeblik, læseren studser, bliver diskurserne, sproget og genreforventningerne synlige for læseren Og i dette møde mellem tekst og læser skabes en ny virkelighed - ikke som mimetisk gengivelse, men som en performativ effekt, der skabes i mødet mellem læser og værk.

Der er ikke noget nyt ved, at kunsten eksperimenterer i gråzonen mellem sprog og virkelighed. Det nye ved halvfjerdsernes kunstneriske projekter er, at nogle forfattere vælger at udføre eksperimenterne i forhold til størrelser som køn og identitet, hverdagen, det politiske eller det sociale liv. Det er denne periodes sammenkobling af avancerede æstetiske eksperimenter og en meget bred interesse for virkeligheden 
i alle dens aspekter, der både berettiger en litteraturhistorisk genoplivning af perioden og kalder på nye litterær-analytiske greb. Indtil man finder et teoretisk sprog til at beskrive disse tendenser, der ser dagens lys i tresserne og halvfjerdserne både i billedkunst, bodyart og litteratur, vil man alt for ofte forfalde til tematiske, traditionelle biografiske eller udviklingspsykologiske betragtninger, når man skal beskrive værkerne. Måske kan de performative teorier netop tilbyde de nødvendige greb til at fremhæve denne kunsts særegne blanding af æstetik og virkelighed. Litteraturhistorisk set vil en afdækning af halvfjerdsernes gryende performative strategier nødvendiggøre en omvurdering af forholdet mellem modernisme, postmodernisme og realisme. Og det vil være med til at skildre baggrunden for halvfemsernes og nullernes mere radikale undersøgelse af vilkårene for repræsentation. Halvfjerdsernes engagement $i$ virkeligheden peger i sidste instans tilbage til avantgardens insisteren på, at kunstens interesse for virkelighedens forskellige aspekter ikke udelukker dens æstetiske relevans.

\section{Noter}

I Det mest karakteristiske eksempel på denne utopiske konstruktion i Thorups forfatterskab, der giver sig til kende som en figur, der ikke meningsfuldt kan beskrives ud fra de traditionelle kønsdikotomier, er transvestitten Daisy i romanen Baby fra 1968. Denne Thorup-roman skal ikke behandles i nærværende artikel, men jeg henviser til Maja Bissenbakker Frederiksens præcise og tankevækkende queer-læsning af Baby og heri af figuren "Daisy" i Begreb om begær. (Frederiksen, 2005).

2 Læs mere om især Suzanne Brøggers og Pablo Henrik Llambías' performative måde at undersøge virkeligheden på i: Louise Zeuthen: "Som sædvanlig mere end villig... Suzanne Brøggers erindringsføljeton genlæst i et performativt perspektiv”, Den Blå Port 71 (2006).

3 Helle Helle siger i et interview med Per Krogh Hansen, at det, der interesserer hende, er det usagte: Selve handlingen, stedet og tidspunktet er en ramme omkring det vigtigste: Personer, der forsøger at forstå hinanden eller nå hinanden eller slippe af med hinanden. Uanset om det lykkes eller ej, er der altid denne rest tilbage imellem dem. De kan se den, men de kan ikke sige, hvad den består af. Citeret fra http://www.danskedigtere.sdu.dk/helle.html

4 For en interessant og perspektivrig diskussion af realismebegrebet henvises til Per Stounbjerg: 2002. Stounbjerg beskriver den realistiske skrivemodus som udspændt mellem stabiliseringsmekanismer og af-automatisering af perceptionen, mellem genkendelse og underliggørelse. Jeg mener, at Thorup netop ved sin overbetoning af det destabiliserende og underliggørende bryder med det, Stounbjerg vil definere som realisme.

5 I "Performativ biografisme", betegner Jon Helt Haarder de værker, der gør brug af eksplicitte biografiske henvisninger uden dog at være traditionelle biografier som performativ biografisme. Disse værker "blotlægger ikke en latent og autentisk livshistorie, som værkets oprindelse, men bruger selvbiografiske stumper som en kras realismeeffekt på et lærred spændt ud mellem kvinden bag værket, kvinden foran værket og fiktionen.” (Haarder 2004: 28) Med termen biografisk irreversibilitet beskriver han netop det fænomen: "at biografiske problemstillinger ikke lader sig holde ude af tekstanalysen", når læseren sidder inde med en viden om forfatteren, om læseren vil det eller ej." (Haarder 2004: 31) 
6 For en grundig og spændende beskrivelse af den performative forskydning i nutidens kunstneriske selvfremstillinger fra "Hvem er kunsteren?" til "Hvor er kunstneren?", kan man læse Rune Gades Kønnet i kroppen i kunsten. Selvfremstillinger i samtidskunsten. Ligeledes har Jane Blocker meget sigende kaldt sin fremragende bog om Ana Mendieta for: Where Is Ana Mendieta? Identity, Performativity, and Exile.

7 Judith Butler skriver i essayet: "Performative acts and gender constitution. An essay in phenomenology and feminist theory": In this sense, gender is in no way a stable identity or locus of agency from which various acts proceed; rather, it is an identity tenuously constituted in time - an identity instituted through a stylized repetition of acts. [...] Significantly, if gender is instituted through acts which are internally discontinuous, then the appearance of substance is precisely that, a constructed identity, a performative accomplishment which the mundane social audience, including the actors themselves, come to believe and to perform in the mode of belief. Selvom Butler her skriver specifikt om køn, gælder betragtningerne også i forhold til identitet i det hele taget. I Gender Trouble fastslår Butler: .... identity is performatively constituted by the very 'expressions' that are said to be its results (33).

8 Amelia Jones: Body Art. Performing the Subject, har inspireret mig med hensyn til, hvordan Judith Butlers performative teorier om køn og identitet kan overføres til kunsten. Af danske teoretikere er Rune Gades Kønnet $i$ kroppen $i$ kunsten. Selvfremstillinger $i$ samtidskunsten meget relevant læsning i forhold til hvorledes køn og identitet kan fremstilles performativt i kunsten.

9 Både Marie-Louise Svane i Danske digtere i det tyvende århundrede (1980) og især Erik SkyumNielsen i Danske digtere i det 20. århundrede (2000) har skrevet meget præcist og grundigt om Kirsten Thorups forfatterskab. Men deres tendens til at overføre fortolkningen af de fiktive personer som splittede og fremmede for dem selv til hele forfatterskabet, reducerer efter min mening forfatterskabets æstetiske rækkevidde. Svane og Skyum-Nielsen ser de hemmelige tekster som forfatterens måde at vise, at "mennesker er mere end det liv de lever" (fx Skyum-Nielsen 2000: 12). Men hermed mener jeg, at de overser den performative pointe med de hemmelige tekster og værkernes øvrige eksponering af forskellige diskurser i det hele taget. Bag Svanes og Skyum-Nielsens fremmedgørelses-, splittelses- og frigørelsesmetaforik ligger der en traditionel subjektopfattelse, hvor selvet opfattes som en statisk psykologisk, eksistentiel eller social konstitution, der er indlejret i personligheden. Denne kerne kan så enten frigøres, altså leves ud og gives sprog og handling, eller den kan forkrøbles i sammenstødet med omverdenen, således at mennesket efterlades splittet og fremmedgjort i forhold til sig selv. I denne optik ses Thorups værker som mimetiske beskrivelser af de fortalte personers, fortællerens - og i sidste ende forfatterens - livtag med virkeligheden, kampen for at frigøre selvet, give det sprog, skrive romaner. Men denne optik er ikke forenelig med den performative tendens, som jeg mener at kunne finde i Thorups værker i stigende grad.

\section{Litteratur}

Jane Blocker: Where Is Ana Mendieta? Identity, Performativity, and Exile (Durham, 1999).

Judith Butler: "Performative acts and gender constitution. An essay in phenomenology and femi-

nist theory", The Performance Studies Reader (London, 2004).

Judith Butler: Gender Trouble (London, 1999) .

Maja Bissenbakker Frederiksen: Begreb om begær, (Odense, 2005).

Rune Gade: Kønnet i kroppen i kunsten. Selvfremstillinger i samtidskunsten (København, 2005). 
Jon Helt Haarder: "Performativ biografisme", i Kritik 167 (2004).

Amelia Jones: Body Art. Performing the Subject (Minneapolis, 1998).

Erik Skyum-Nielsen: "Kirsten Thorup", i Danske digtere i det 20. århundrede (København, 2000).

Per Stounbjerg: "Tilforladelighed og underliggørelse. Om realismen" i Om som om. Realisme i teori og nyere kunst (Århus, 2002).

Louise Svane: "Kirsten Thorup", i Danske digtere i det tyvende århundrede (København, 1980).

Kirsten Thorup: Bonsai (København, 2000).

Kirsten Thorup: Himmel og helvede (København, 1982).

Kirsten Thorup: Lille Jonna (København, 1977).

Louise Zeuthen: "Som sædvanlig mere end villig... Suzanne Brøggers erindringsføljeton genlæst i et performativt perspektiv”, Den Blå Port 71 (København, 2006). 